\title{
A new assemblage of ray-finned fishes (Teleostei) from the Lower Oligocene "Schistes à Meletta" from the Glières plateau, Bornes Massif, eastern France
}

\author{
Antoine Pictet $\cdot$ Jérôme Chablais $\cdot$ Lionel Cavin
}

Received: 22 November 2012 / Accepted: 3 May 2013/Published online: 16 November 2013

(C) Swiss Geological Society 2013

\begin{abstract}
A recently discovered fish assemblage from the "Schistes à Meletta" facies (Lower Oligocene) of the Glières Plateau, Bornes Massif, Haute-Savoie, eastern France is described. The assemblage, comprising specimens ranging from fully-articulated skeletons to isolated scattered ossifications, is composed of Anenchelum cf. glarisianum, Pristigenys sp., Fistularia sp., Caranx cf. glarisianus alongside indeterminate teleosts. This new assemblage greatly increases the fish diversity previously known from the "Schistes à Meletta" of this area. The fauna shows biogeographic affinities with assemblages from the Peritethys domain, in particular from the Helvetic molassic basin and from the Paratethys. The genera identified at the Glières locality are represented today by species living in tropical nearshore environments together with species from the open sea. A possible explanation is that the environment of deposition was rather deep, and that shallow-water fishes were brought in by turbidity currents.
\end{abstract}

Keywords Fish - Taxonomy - Cenozoic · Fistularia . Pristigenys · Anenchelum · Caranx · Palaeobiogeography

Editorial Handling: C. Pirkenseer \& D. Marty.
Résumé Un assemblage de poissons a été découvert dans le faciès des Schistes à Meletta (Oligocène inférieur) du plateau des Glières dans les Massif des Bornes, est de la France. La faunule, représentée par des spécimens dont la préservation consiste en spécimens parfaitement articulés et en ossifications isolées, comprend Anenchelum cf. glarisianum, Pristigenys sp., Fistularia sp., Caranx cf. glarisianus ainsi que des téléostéens indéterminés. Cette faune augmente de manière importante notre connaissance des ichtyofaunes des Schistes à Meletta de cette région. Elle présente des affinités biogéographiques avec les assemblages du domaine péritéthysien, en particulier du bassin molassique helvétique et de la Paratéthys. Les genres découverts dans la localité du Plateau des Glières sont représentés aujourd'hui par des espèces tropicales d'environnements littoraux accompagnés de formes de milieux plus profonds. Une explication possible à ce mélange est que le milieu de dépôt était relativement profond, les formes de milieux moins profonds ayant pu être amenées par des courants turbiditiques.

\section{Institutional abbreviations}

MHNG GEPI Natural History Museum of Geneva collection of the Department of geology and palaeontology

\section{Introduction}

The Meletta Shale facies is regarded in the Alps either as a Member or as a Formation (Charollais et al. 1980, 1988).

Comparable Oligocene marine fish assemblages from the Euroasiatic territory are shown in Fig. 1. Fish-bearing sediments are developed from Western Europe to the Transcaspian Basin and occur in the North Sea Basin (e.g., 
Boom clay, Leriche 1910), Rhine Graben (e.g., Frauenweiler, Pharisat and Micklich 1998; Mainzer Becken, Weiler 1928; Allschwill, Weiler 1955; Froidefontaine, Pharisat 1991), Carpathians (e.g., Czech Republic, Gregorová 2011; Poland, Kotlarczyk et al. 2006; Hungary; Romania, Constantin 1999) and Caucasus (e.g., Bannikov 2010).

In the Alpine region, the fish localities belong to several different tectonic units: (i) Prealps - Entlebuch (Fröhlicher and Weiler 1952), Bavaria (Weiler 1932); (ii) Helveticum Massif des Bauges, Glières Plateau, Glarus (Wettstein 1886); (iii) Southern Alpine Foreland - Chiavon (Bassani 1889). These localities have an important palaeogeographical position between the northern Paratethys basin and the southern Tethys basin, which also includes the Iranian Elam locality (Simionescu 1905; Arambourg 1967).

In the northern subalpine ranges, the Meletta Shale facies is generally very rich in isolated scales, which are referred informally to the fish genus Meletta, and has yielded so far a single sub-complete specimen of Palaeorhynchus in the Champlaitier syncline (Gaudant et al. 1994).

In 2007, two of us (AP and JC) discovered on the Glières Plateau (Haute-Savoie Department, $45^{\circ} 57^{\prime} 41.53^{\prime \prime} \mathrm{N}$; $\left.6^{\circ} 19^{\prime} 42.51^{\prime \prime} \mathrm{E}\right)$ several fragments of articulated fishes. A small excavation was conducted the same year and about ten specimens were collected, including for most of them parts and counterparts. The specimens were found in an about 1.7 meter thick, well-laminated interval of the Meletta Shales, that crops out along the bank of a small rivulet bed (Fig. 2a). They were preserved in between laminae of the slightly marly shale. All studied material is deposited in the Department of geology and palaeontology of the Natural History Museum of Geneva (MHNG GEPI).

\section{Geological setting}

The Glières Plateau belongs to the Bornes Massif and forms the limit between the Molassic Basin of the Bornes Plateau to the west, and the Aiguilles Rouges and MontBlanc crystalline Massifs in the east (Fig. 2b). Tectonically, the Glières Plateau is a syncline with a SW-NE axis that dips towards the Cenise Plateau, which is located on the eastern side of the Borne River (Fig. 3).

The Glières Plateau is constituted of a series of deposits ranging in age from the early Cretaceous to the Miocene (Fig. 2c). The series comprises from bottom to top: (i) sandy limestones ('Kieslkalk') with abundant sea-urchins at the top (Hauterivian-Barremian); (ii) rather deep-water

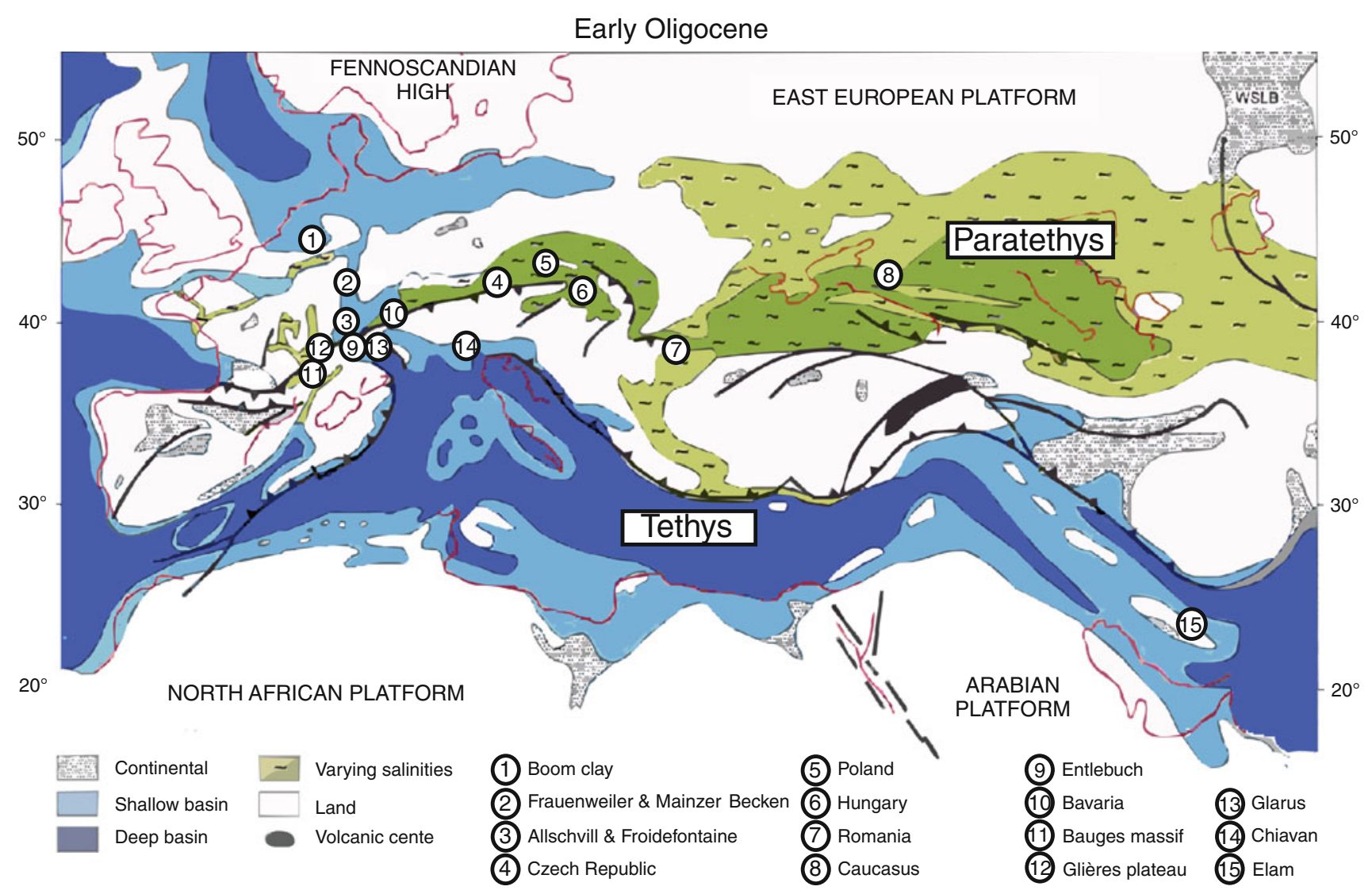

Fig. 1 Palaeogeographical map of the Tethys and Paratethys in the Early Oligocene with locations of the main fish assemblages. Palaeogeographical map modified from Meulenkamp and Sissingh (2003) and locations of the fish assemblages modified from Pharisat (1991) 

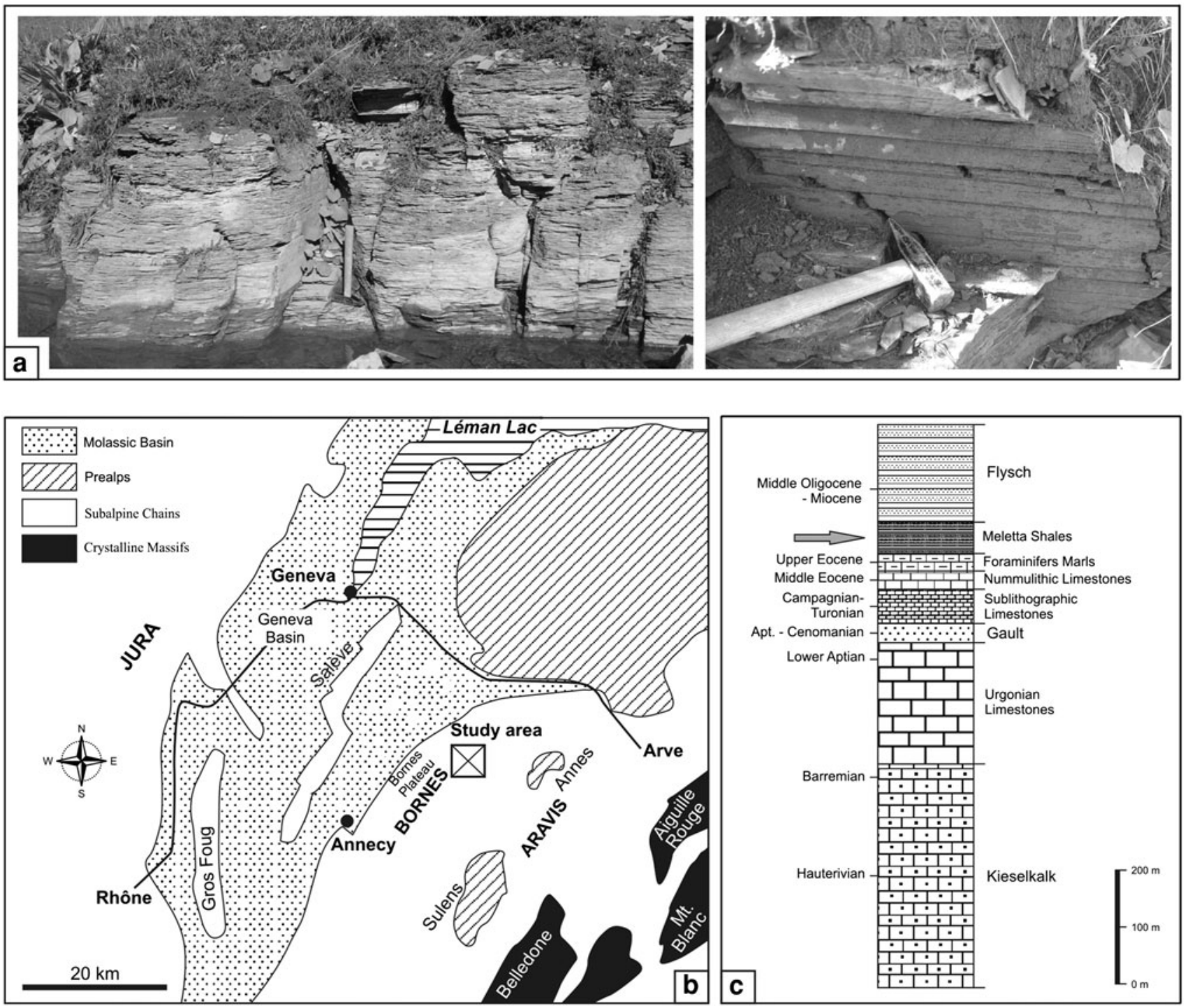

Fig. 2 a Two views of the outcrops of the Meletta Shales that yielded the fish remains. b Simplified geological map of the Geneva area with the location of the studied area (frame) in the Subalpine range and the Bornes Massif (modified from Schegg 1993). Coordinates of the site: $45^{\circ} 57^{\prime} 41.53^{\prime \prime} \mathrm{N} ; 6^{\circ} 19^{\prime} 42.51^{\prime \prime}$ E. c Stratigraphical section of the Subalpine area as visible in the Glières Plateau (modified from Charollais and Badoux 1990)

sporadically along the flanks of the synclines of the Bornes Massif (Fig. 3) (Charollais et al. 1980). This is also the case for the Meletta Shales outcrop preserved in the NE part of the Glières Plateau that yielded the fish assemblage described here (Fig. 3). At this locality, the dark maroon to dark grayblue Meletta Shales form subhorizontal and finely-laminated beds ranging from a few millimetres to a few decimetres in thickness (Fig. 2c). The maximum total thickness of the Meletta Shales in this area reaches about $30 \mathrm{~m}$.

The Meletta Shales has a wackstone texture containing abundant scales and fish debris embedded in a matrix composed of a large proportion of clay, fine detritic sandstone, micas and organic matter including plant remains. Charollais et al. (1980) provided a faunal list of the Meletta Shales and nummulitic limestones, are eroded and only crop out 
Fig. 3 Distribution map of the Meletta Shales and Foraminifera Marls in the synclines of the Bornes Massif, northern subalpine domain (modified from Charollais et al. 1980)

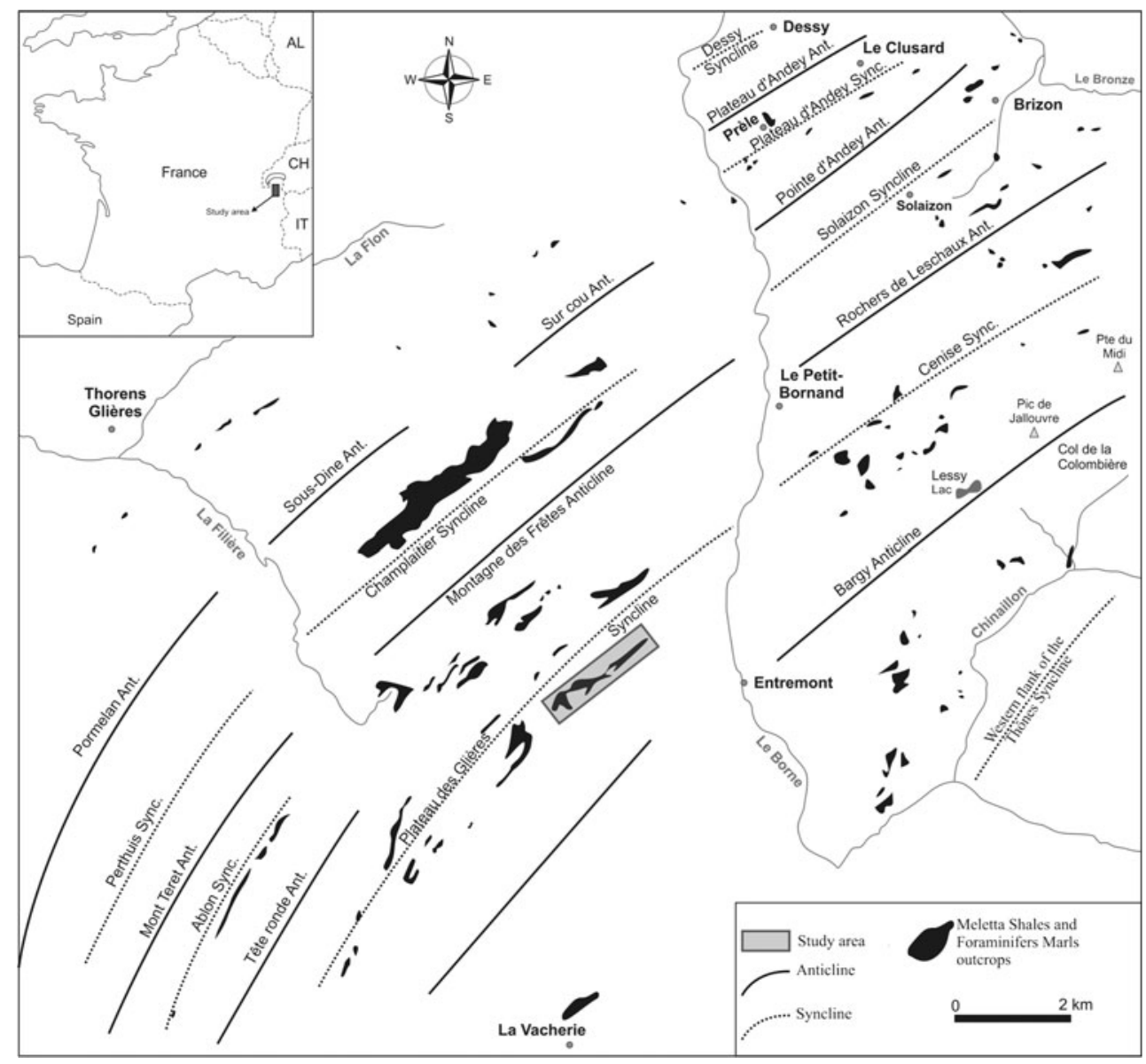

of the Foraminifera Marls from the northern subalpines ranges including the Bornes Massif: it contains pollen and spore assemblages, dinoflagellates, benthic and planktonic foraminifers, ostracodes and rare nannofossils. The Meletta Shales differ from the Foraminifera Marls because of the quasi absence of benthic and large planktonic foraminifers and the occurrence of small foraminifers.

The biostratigraphical analysis (palynomorphs and planktonic foraminifers) of the Meletta Shales gives an age ranging from the Early Oligocene to the early Middle Oligocene. The depositional environment of the Meletta Shales corresponds to a more confined or even closed environment when compared to the underlying Foraminifer Marls, which were deposited in an epipelagic to pelagic open environment. The gradual restriction of the environment, associated with a drop of temperature in Northern Europe, is probably related to the progressive closure of the ocean to the North of the Alps during the Oligocene (Charollais et al. 1980).

\section{Systematic palaeontology}

Order Perciformes Bleeker, 1859

Family Trichiuridae Rafinesque, 1810
Subfamily Aphanopodinae Gill, 1864 Genus Anenchelum Blainville, 1818

Anenchelum cf. glarisianum Blainville, 1818

Material. MHNG GEPI V5559, part and counterpart of a subcomplete specimen with a disarticulated skull and the postcranial skeleton, except the caudal region (Fig. 4a-c); MHNG GEPI V5560, a partial and disarticulated specimen (Fig. 4d-f); MHNG GEPI V5561, an isolated tooth.

Description. In all specimens the skull is disarticulated. The posterior half of the braincase (Bc.) is preserved on MHNG GEPI V5559 (Fig. 4a-c), but the bones are crushed and no limit between ossifications can be distinguished. The only identifiable element of the upper jaw is a premaxilla (Pmx.) on MHNG GEPI V5560 (Fig. 4d-e). It has a typical elongated and curved outline with 12 medium-sized teeth, each bearing a constriction at its base.

Fig. 4 Anenchelum cf. glarisianum, Early Oligocene of the Glières Plateau, photographs and semi-interpretative line drawings. a-c MHNG GEPI V5559. d-f MHNG GEPI V5560. $B c$. braincase, $B r$. branchiostegal rays, $\mathrm{Cl}$. cleithrum, $\mathrm{Co}$. coracoid, $\mathrm{Hm}$. hyomandibula, Iop. Interopercle, mand. mandible, $O p$. opercle, pec.f. pectoral fin, $P m x$. premaxilla, Pty. pterygiophores, n.a. neural arches, $Q$. quadrate, Sop. subopercle; $V$. vertebrae 
a

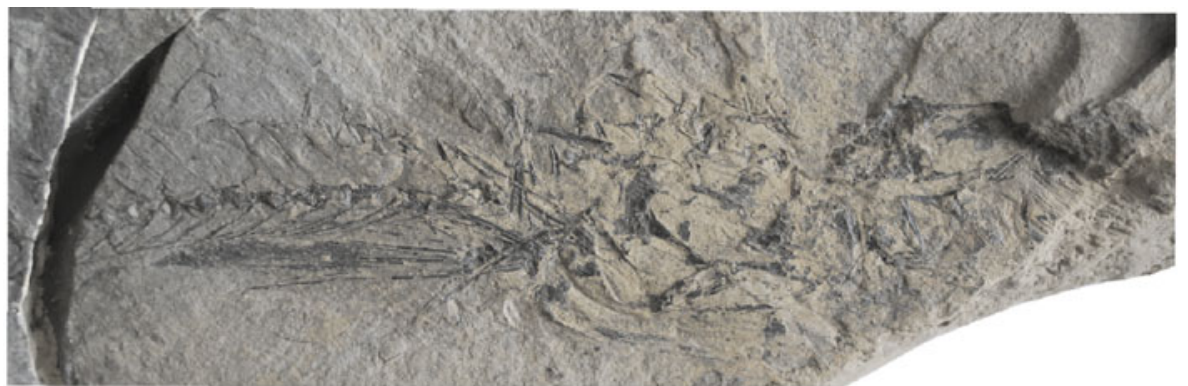

b

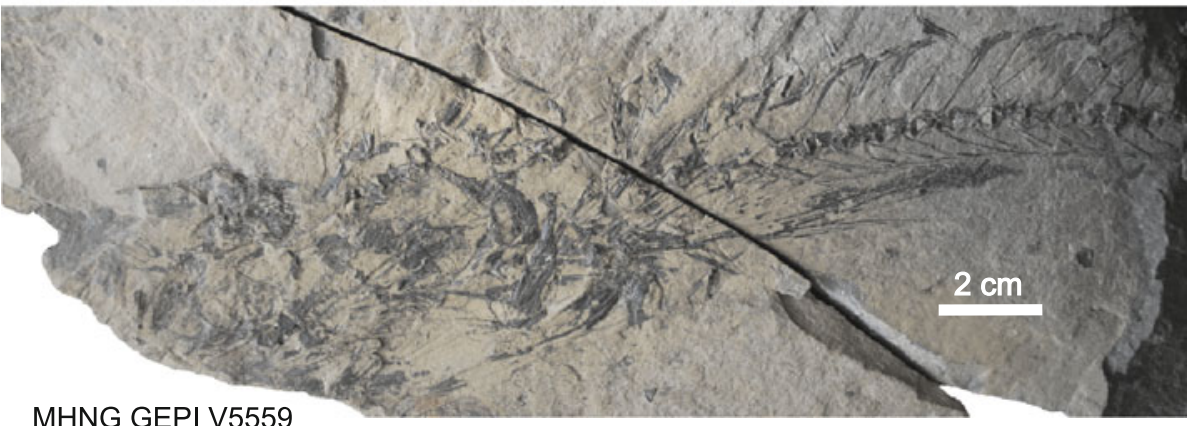

C

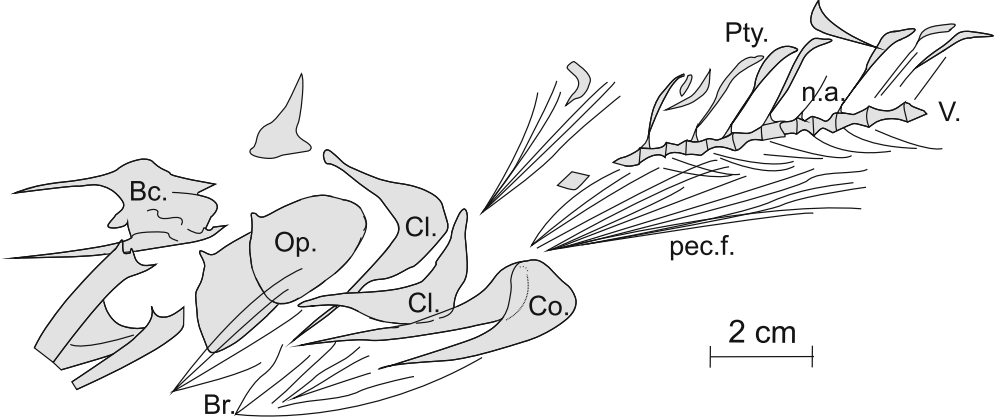

d

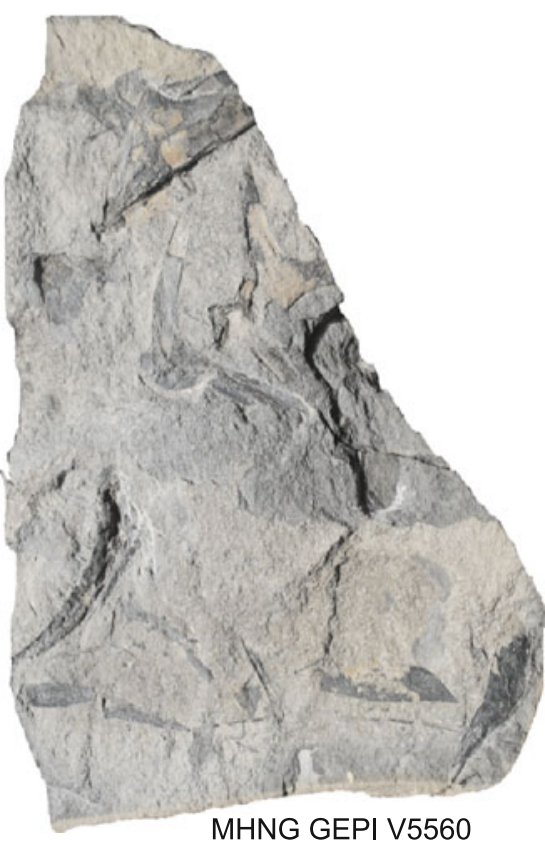

e

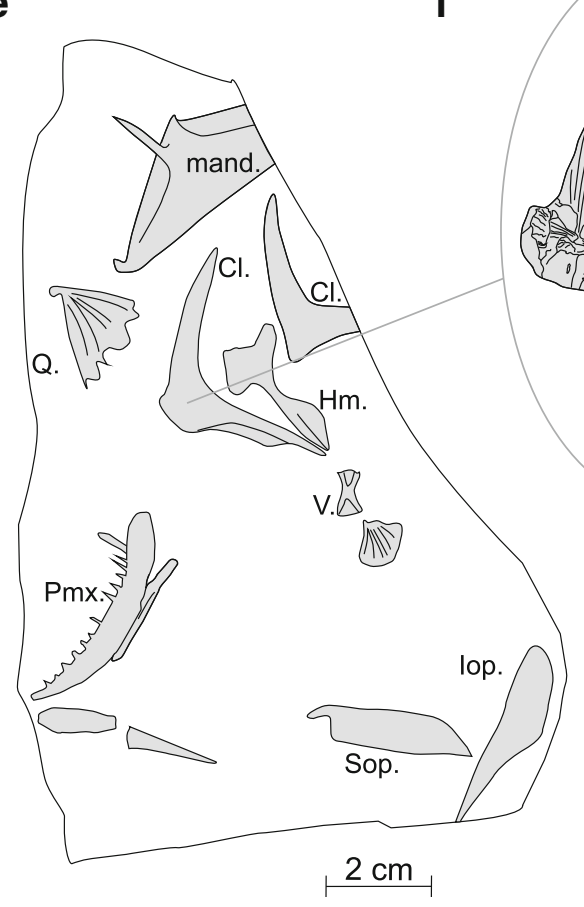



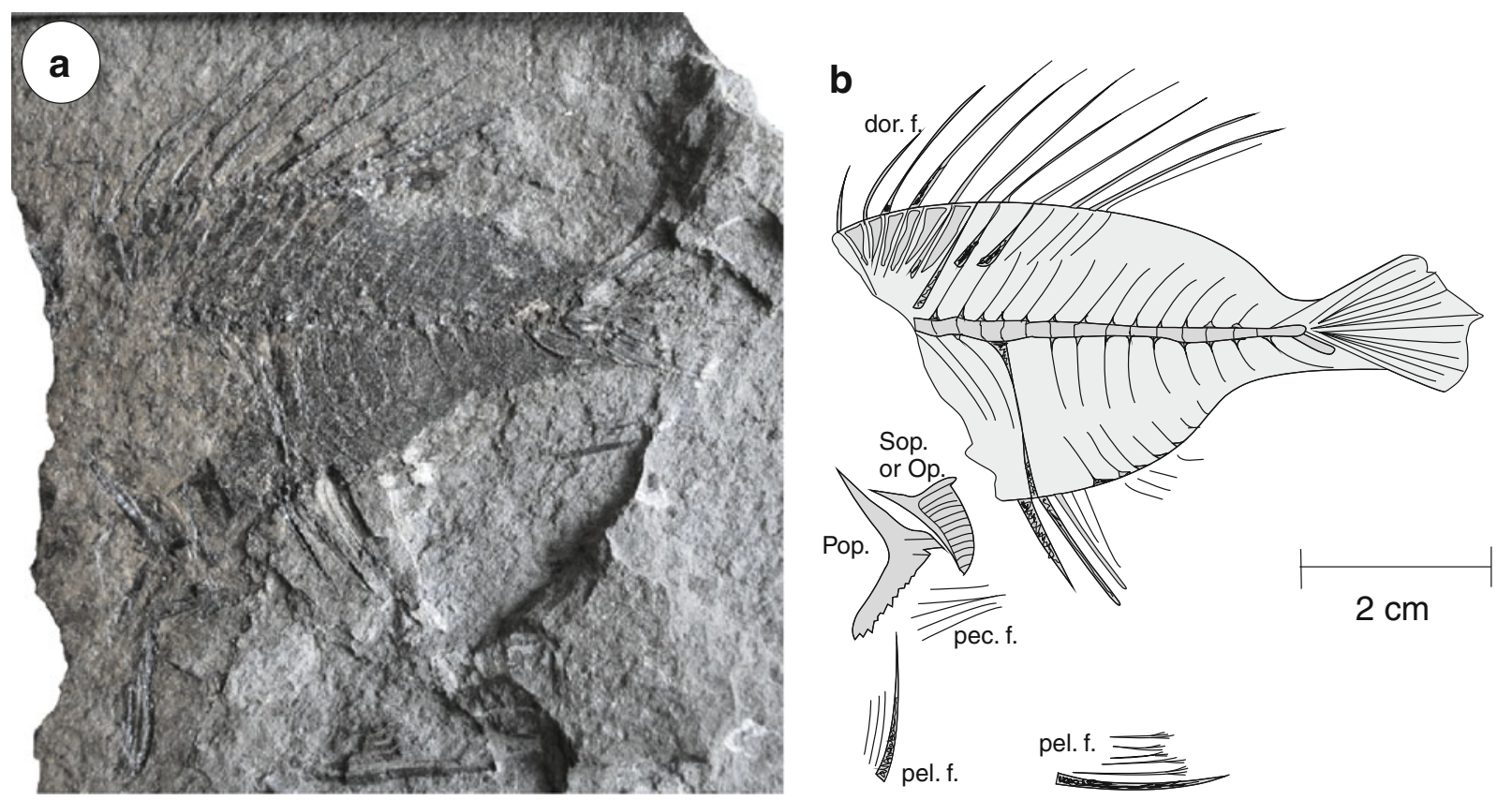

MHNG GEPI V5562
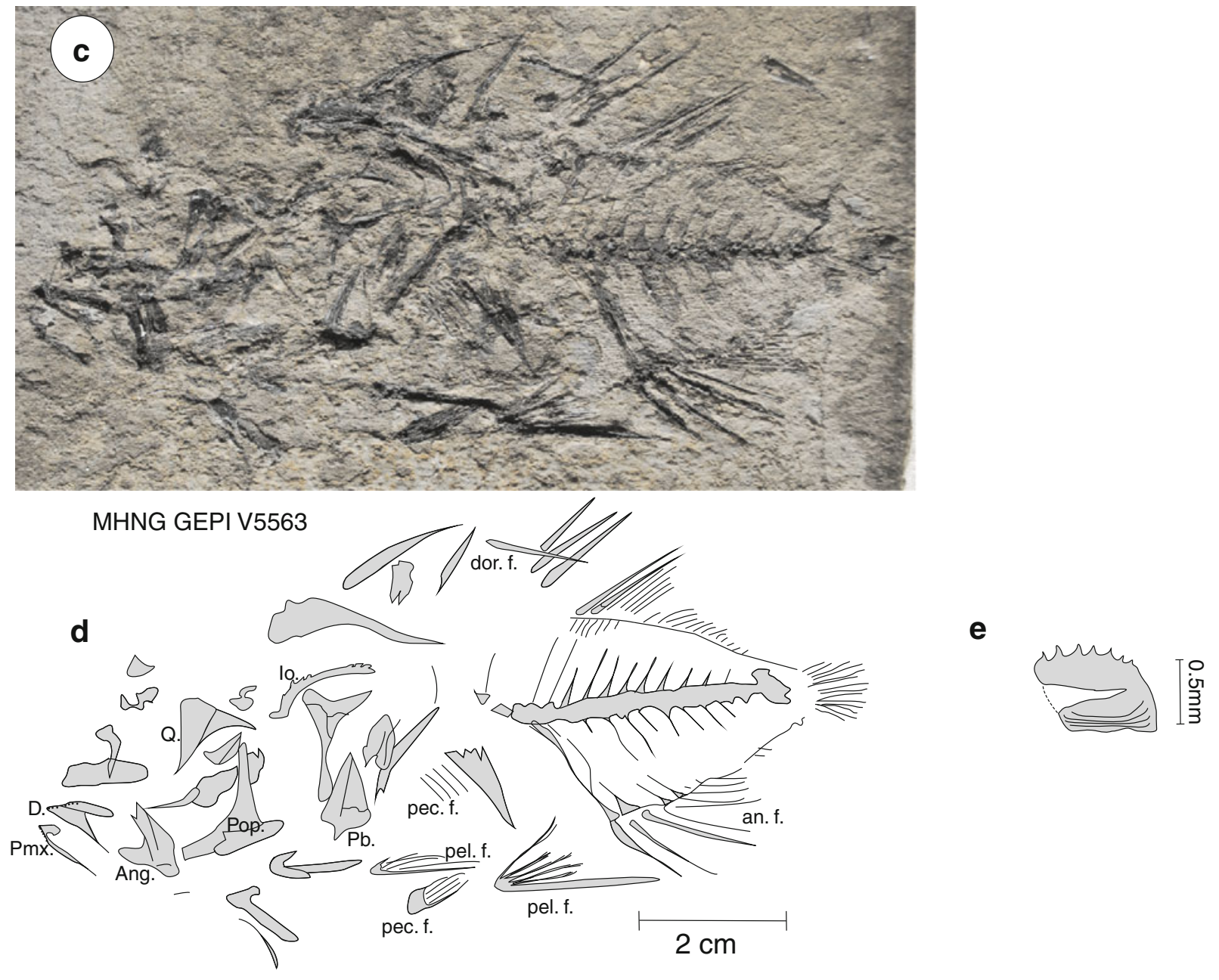
4Fig. 5 Pristigenys sp., Early Oligocene of the Glières Plateau, photographs and semi-interpretative line drawings. a-b MHNG GEPI V5562. c-d MHNG GEPI V5563. Ang. angular, D. dentary, dor. $f$ dorsal fin, $I o$. infraorbitals, $O p$. opercle, $P b$. pelvic bones, pec.f pectoral fin, pel.f pelvic fin, Pmx premaxilla, Pop. preopercle, $Q$. quadrate, Sop. Subopercle. e Detail of an isolated scale showing the identation on the posterior margin

The anterior extremity of the bone is slightly enlarged and bears on its medial side a proportionally huge caniniform tooth, still partly covered with matrix. A second caniniform tooth, present in the genus Anenchelum (Gregorová 2010), is not visible but we cannot exclude that it is present but covered with matrix. The posterior part of the mandible is preserved on MHNG GEPI V5560. The articular facet is situated very posteriorly, close to the posterior corner of the mandible (mand.). The coronoid process forms a triangle with an anteriorly tilted upper corner. In MHNG GEPI V5560, an isolated quadrate (Q.), triangular in shape, is preserved not far from the mandible, as well as a hyomandibula (Hm.). The latter shows a broad cruciform dorsal process separated by a constriction from the narrow vertical shaft. Both opercles (Op.) and cleithra $(\mathrm{Cl}$.), traces of the branchiostegal rays (Br.), as well as possibly subopercles (Sop.) are visible on MHNG GEPI V5559 (Fig. 4c). Only the imprints of both opercles are visible and their shape is reconstructed in Fig. 4c. The opercle is proportionally small, longer than deep and bears at its anterodorsal corner a small process typical for Trichiuridae (Gago 1998). Subopercle and interopercle (Iop.) are preserved, slightly shifted in MHNG GEPI V5560 (Fig. 4d-e). Both cleithra, preserved on MHNG GEPI V5560 and MHNG GEPI V5559, are well-ossified bones forming a right angle between both limbs. Both coracoids (Co.) are also present in MHNG GEPI V5559. The isolated tooth (MHNG GEPI V5561), ca. $8 \mathrm{~mm}$ in length, is gently curved and bears a little hook at its tip. It probably comes from the anterior extremity of a premaxilla.

The vertebral column of MHNG GEPI V5559 shows 64 very elongated centra, 31 are precaudal, but the posterior most vertebrae (V.) are not preserved. The neural arch (n.a.) extends along the whole length of the centrum. 29 pairs of elongated ribs articulate directly with their respective centrum. Neural and haemal spines are posteriorly inclined and decreased in size posteriorly.

The pectoral fins (pec.f.) are situated low on the body. They consist of ca. 15 rays with a length equivalent to 12 precaudal centra. The pterygiophores (Pty.) contact the dorsal part of the neural spines in the anterior part of the body. They are formed by a long, thin and slightly sigmoid vertical limb that enlarged and curved backward distally. Pelvic, anal, dorsal and caudal fins are not preserved.

Discussion. Although the diagnostic characters of the genus Anenchelum are not visible on our material
(Gregorová 2010), the arrangement and shape of most of the preserved ossifications of the skull, in particular a premaxilla with a concave margin with at least ten small teeth and a large fang anteriorly, together with the shape of the cleithrum, an elongated body and the peculiar arrangement of the dorsal pterygiophores form a combination of characters typical for the genus Anenchelum (Jerzmanska 1968; Gregorová 2010). Species of Anenchelum are distinguished mainly on the basis of meristic features, which are not preserved in our specimens.

Anenchelum glarisianum is the most frequent trichiurids in European Oligocene localities. Consequently, pending further discoveries, we refer this taxon to Anenchelum cf. glarisianum.

Family Priacanthidae Gill, 1872

Genus Pristigenys Agassiz, 1835

Pristigenys sp.

Material. MHNG GEPI V5562, part and counterpart of a sub-complete specimen with a disarticulated skull (Fig. 5a-b); MHNG GEPI V5563, part and counterpart of a sub-complete specimen with disarticulated skull (Fig. 5c-d).

Description. Both specimens are ca. $10 \mathrm{~cm}$ in total length, calculated by inference before disarticulation of the skulls. They are oval in outline with strong spines in front of the pelvic, dorsal (dor. f.) and anal fins (an. f.). The maximum depth of the body equals ca. $1 / 3$ of its standard length. The head is short, with a small gape and the orbit is large.

Both skulls are disarticulated but show some identifiable bones. In MHNG GEPI V5563 (Fig. 5c-d), two series of poorly-preserved infraorbitals (Io.), one shifted near the snout and the other shifted posteriorly, are formed by a series of shallow ossifications with well-developed denticulations preserved on some sections of their ventral margin (visible dorsally in Fig. 5d) because the bones are upside down). In this specimen a quadrate is visible as an almost equilateral triangle, and other fragments of the suspensorium are preserved. The angular (Ang.) is poorly preserved on MHNG GEPI V5563, but it shows a moderately deep coronoid process. The dentary (D.), preserved on both specimens, is dug by a deep posterior notch for the angular and it bears on its oral margin minute villiform teeth. A row of teeth, similar in shape, is present on the premaxilla, which is incompletely visible and shifted below the mandible in MHNG GEPI V5563. A rounded, articular head is present at the anterior extremity of the premaxilla. Both individuals show the propercle (Pop.) with two limbs arranged at right angle and with a well-developed spine at its posteroventral corner. The posterior margin of the vertical limb is almost smooth, except a spine situated in the ventral quarter of the depth of the bone. At least three 
posterior diverticulae of the sensory canal are visible as shallow tubes that open along the posterior margin of the bone. The horizontal limb is almost as long as the vertical one and bears posteriorly-oriented denticles on its ventral margin. A roughly triangular ossification, poorly preserved on MHNG GEPI V5562, is regarded as either a subopercle or an opercle (Fig. 5a-b), but the other bones of the opercular series are much damaged and cannot be identified. Other bone fragments are present, but difficult to identify and do not provide much additional information.

The vertebral column contains at least 19 vertebrae, thereof 13 caudal. The abdominal centra are as long as deep, while the caudal ones become proportionally longer than deep backward. Each caudal centrum bears neural and haemal arches extending along the whole centrum length, and are prolonged by neural and haemal spines respectively. These spines stop in the middle between the vertebral column and the dorsal versus ventral margins of the body. The available ural skeletons are poorly preserved, but traces of at least two large hypural plates are visible in MHNG GEPI V5563.

The pectoral fins are poorly preserved and shifted along the ventral border of the specimens; they show at least five rays. In MHNG GEPI V5563 a pair of sutured triangular ossifications, with a medial thickening and an anterior process, corresponds to the pelvic bones $(\mathrm{Pb}$.), which are thoracic in position, although slightly shifted dorsally in this specimen. The pelvic fins contain circa ten rays preceded by an elongated spine extending posteriorly up to the first third of the anal fin. The proximal radials (pterygiophores) of the dorsal fin are well developed and formed by a long central thickened axis extending posteriorly by a blade of bone. The anterior, most proximal radial supports the first two spines of the dorsal fin, and is triangular in shape. The structure made by the series of proximal radials forms a continuous dorsal ossified median wall, at least in the abdominal region of the fish. The distal radials, although much poorly preserved, constitute a continuous series of ossification along the dorsal margin of the body. The dorsal fin starts just behind the occiput and stops at the level of the fourth preural centrum. It is formed by at least ten spines increasing in size posteriorly, which are followed by more than ten rays decreasing in size posteriorly. The anal fin is supported by a series of proportionally small pterygiophores, except the first one, which supports the first three spines and extends dorsally almost to the level of the haemal arch. The anal fin is composed of three strong spines followed by circa seven rays decreasing is length posteriorly. The caudal fin is short and apparently contains 19 rays.

The body is covered with small ctenoid scales, with the denticulated posterior margin comprising numerous spines (Fig. 5e).

Discussion. The general body proportions, the structure of the dorsal and pelvic fins and the morphology of the scales allow referring these specimens with caution to the genus Pristigenys (Taverne and Nolf 2010). In particular, these specimens possess 13 caudal vertebrae, 10 spines in the dorsal fin and 3 spines in the anal fin (the number of abdominal vertebrae and soft rays in the fins are uncertain in our material) as in Pristigenys spinosus (Pharisat 1991). Characters of Pristigenys visible in the Glières material that differ from the zeiform Capros, which share a superficial similar morphology, close meristic features and which occurs in coeval deposits, are: (1) the dorsal fin forms a regular rounded outline in Pristigenys, while in Capros it is divided by a notch separating the spinuous from the membranous portion of the fin, which gives an impression of two dorsal fins and; (2) the occurrence of numerous denticles on the posterior margin of the scales in Pristigenys (Starnes 1988), contra five denticles only in Capros (Jerzmanska 1968). Because of the poor preservation of meristic characters, we refer these specimens to the genus Pristigenys with no specific determination.

Family Carangidae Rafinesque, 1815

Genus Caranx Lacépède, 1802

Caranx cf. glarisianus (Agassiz, 1844)

Material. MHNG GEPI V5566, part and counterpart of an articulated skeleton with the skull missing and the caudal fin detached and shifted (Fig. 6).

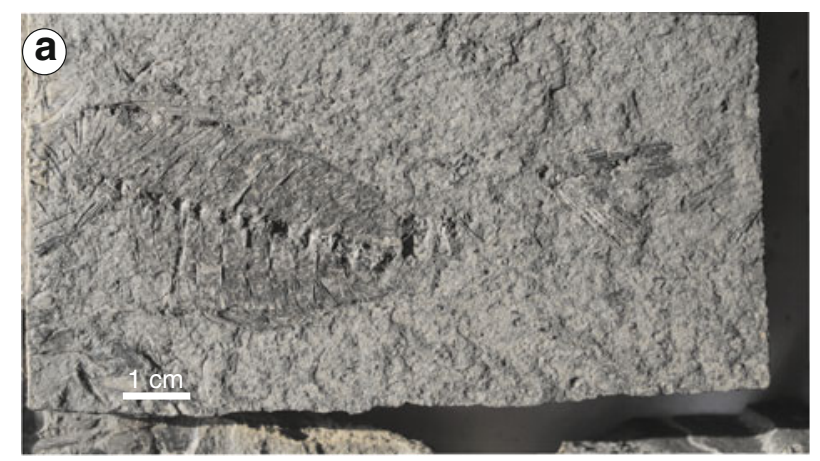

MHNG GEPI V5566

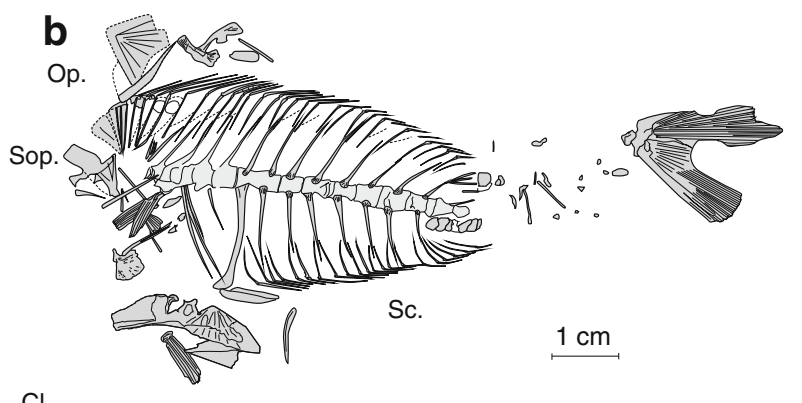

Cl.

Fig. 6 Caranx cf. glarisianus, Early Oligocene of the Glières Plateau, photograph and semi-interpretative line drawing. a-b MHNG GEPI V5566. $\mathrm{Cl}$. cleithrum, $\mathrm{Op}$. opercle, $\mathrm{Sc}$. scale, Sop. subopercle 
a

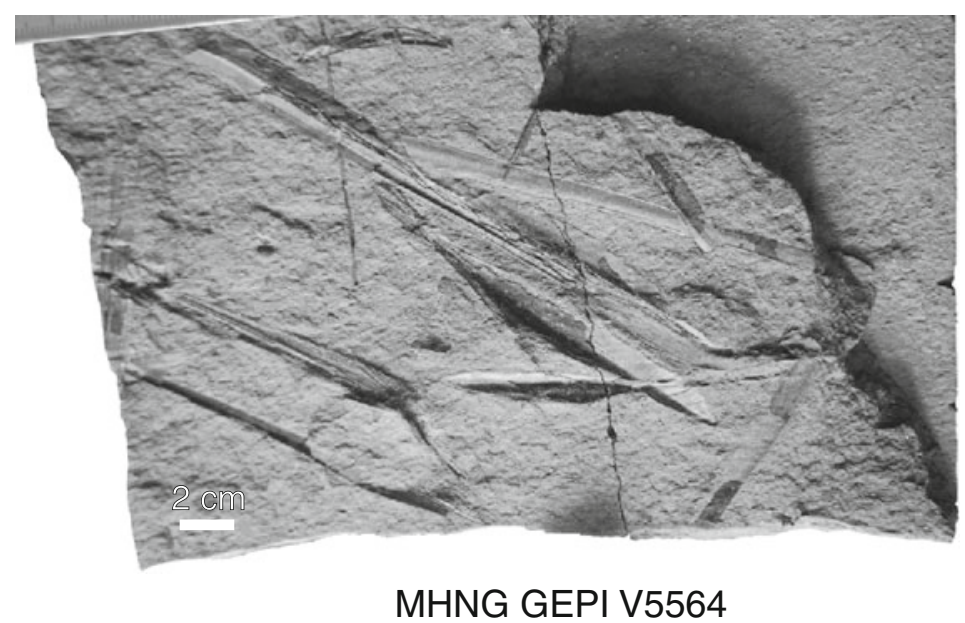

b

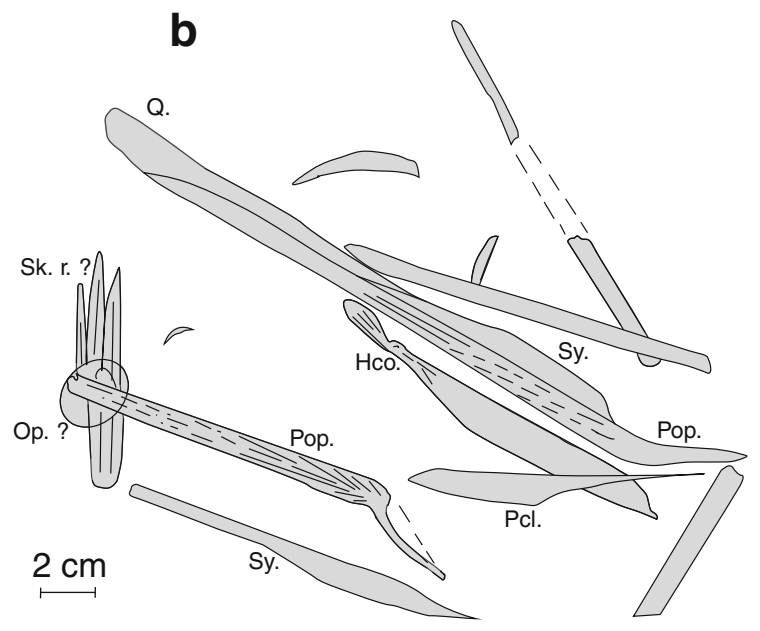

Fig. 7 Fistularia sp., Early Oligocene of the Glières Plateau, photograph and semi-interpretative line drawing. a-b MHNG GEPI V5564. Hco, hypocoracoid, $Q$. quadrate, $O p$. opercle, Pcl. postcleithrum; Pop. preopercle, Sk.r. skull roof, Sy symplectic

Description. The preserved portion of the body is oval in shape. Circa 15 vertebrae, with 12 caudal, are observed, but more abdominal and caudal vertebrae were present but not preserved. The total number of vertebrae, however, was low and probably less than 25 . The neural spines are thin and high, reaching two-thirds of the body depth above the vertebral column. Each inter-neural space is occupied by two, or one in the anterior part of the body, basal radials (pterygiophores). Each pterygiophore bears an ossified lamina located posteriorly to the axis and the anterior radials are slightly inclined, with their proximal part oriented backwards. The dorsal fin runs along the whole preserved part of the dorsal margin of the body, i.e., posteriorly close to the caudal peduncle. Eight spines are present in the anterior portion of the dorsal fin, which are followed by an unknown number of rays. The abdominal cavity is short. The anal fin is supported by circa 20 basal radials, but additional ones were possibly present more posteriorly. They extend by pairs or by triplets in interhaemal spaces, in a pattern similar to the arrangement of the dorsal radials. The anal fin is composed of two strong and short spines, separated by a gap from an indeterminate number of soft rays (at least 15). Few details of the ural skeleton and of the caudal fin are recognizable, except that the caudal fin is forked. The scales are cycloid. A row of circa seven scales, much larger and thicker than the other ones, are preserved slightly ventrally to the vertebral column in the caudal peduncle region.

Discussion. The specimen is very close, or co-specific, with Caranx glarisianus because of the following set of characters (Pharisat 1991): less than 25 vertebrae (24 in G. glarisianus), 8 spines in front of the dorsal fin, 2 short spines separated by a gap from the rays in the anal fin, cycloid scales and a series of specialised thickened scales along the caudal peduncle. Because the specimen is poorly preserved and the meristic features are uncertain, we refer it to Caranx cf. glarisianus.

Order Gasterosteiformes Goodrich 1909

Family Fistulariidae Blainville, 1818

Genus Fistularia Linnaeus, 1758

\section{Fistularia sp.}

Material. MHNG GEPI V5564, part and counterpart of a partial disarticulated skull (Fig. 7a-b).

Description. The antorbital part of the skull is extremely elongated in this genus, and most of the corresponding bones are highly derived, shaped as elongated ossified lamina. Both preopercles are preserved on MHNG GEPI V5564 (Fig. 6a-b). These ossifications consist of a very elongated horizontal limb tapering anteriorly and ornamented with aligned small tubercles radiating from the posteroventral corner, and of a proportionally very short vertical limb arranged at an angle of $140^{\circ}$ with the horizontal limb. Along the dorsal margin of the horizontal limb of the preopercle lie two elongated bones roughly triangular in shape. The anterior one is identified as the quadrate, although its articular head is not preserved on the specimen, and the posterior one is regarded as the symplectic (Gregory 1933). An elongated ossification with a constriction in the anterior (?) fourth of its length and with a medial crest delimitating two faces is identified as a hypocoracoid (Starks 1902; labelled 'dco' in Gregory 1933 probably for 'dorsal coracoid'). Other fragments are 
possibly pieces of the skull roof, as well as an opercle, together with other non-identifiable elements.

Discussion. The extreme elongation of the ossifications from the anterior part of the head, in particular the typical shape and ornamentation of the preopercles, characterises with confidence the genus Fistularia.

Danil'chenko (1960) mentioned four extinct species of Fistularia: F. longirostris (Blainville) from the Eocene of Italy, F. koenigi (Agassiz) from the Oligocene of Glarus, $F$. licatae (Sauvage) from the Late Miocene of Sicily and $F$. contermina (Danil'chenko 1960) from the Early Oligocene of Caucasus. The specific recognition of both Oligocene species is based on meristic characters of the dorsal and anal fins that prevent us to identify more precisely the specimen from the Plateau des Glières, which is regarded here as Fistularia. sp.

Other fragments of fishes, most fragmentary and some articulated, are present in our sample but have not been identified so far. They are regarded here as Teleostei. i. s.

\section{Palaeogeography and palaeoenvironment}

The assemblage from the Glières Plateau shows palaeobiogeographical affinities with the Peritethyan domain, in particular with the genera Anenchelum, Pristigenys and Caranx, which are also known in the Glarus assemblage of the Helvetic molassic basin (Agassiz 1844; Wettstein 1886; Rath 1859) and in the Carpathian and Caucasian Paratethys (Heckel 1850; Kramberger 1879; Paucã 1930, 1934; Jonet 1958; Horbatsch 1956; Danil'chenko 1962).

Fistularia, a genus present in Glarus and in the Caucasus, is a fish that lives today in near-shore, tropical environment, close to an emerged land as indicates the abundance of plant remains. Living Pristigenys and Caranx species are also tropical, and inhabit costal to more open marine environments. The living Aphanopodinae, to which belongs Anenchelum are benthopelagic fishes with a depth range between 200 and 1,700 meters (Gregorová 2010). The presence of relatively open-marine forms together with littoral forms could be explained by turbidity currents (Charollais and Wellhäuser 1963; Charollais et al. 1980) that brought material from shallow waters towards deeper marine environments.

The abundance of organic matter and of the profusion of fish remains in the Meletta Shales are strong indicators of a dysaerobic environment, possibly caused by the confinement of the basin (Martini 1968; Gorin et al. 1989). This sea was formed during the Early Oligocene, and then became isolated from the Paratethys following the uplift of the Alps, of the Carpaths, of the Dinarids, of the Taurus and Elbourz. Although generally connected to the Tethys, this sea may have been confined because of the occurrence of thresholds, as it is the case in the Black Sea today.

Acknowledgments This article is dedicated to the late Professor Jean-Pierre Berger, for his very important contributions to the geology and palaeontology of the Swiss Molasse. With his decease, we lost an esteemed colleague and a true friend. The authors are indebted to Růžena Gregorová (Brno) and Jean Gaudant (Paris), who performed thorough reviews and provided constructive comments and very useful information, which considerably improved the manuscript. We also thank Pierre-Alain Proz (Geneva) and Jean-Luc Chavan (Geneva) for their help in the field and for the preparation of some of the specimens.

\section{References}

Agassiz, L. (1844). Recherches sur les poissons fossiles. Neuchâtel: Tome IV.

Arambourg, C. (1967). Résultats scientifiques de la mission C. Arambourg en Syrie et en Iran. II. Les poissons Oligocènes de l'Iran. Notes et Mémoires sur le Moyen-Orient, Muséum national d'Histoire Naturelle, Paris, 8, 11-210.

Bannikov, A. F. (2010). Fossil Acanthopterygian fishes (Teleostei, Acanthopterigii) (p. 244). Moscow: Russian Academy of Science.

Bassani, F. (1889). Ricerche sui pesci fossili di Chavon (Strati di Soltzka - Miocene inferiore). Atti delle Reale Accademia delle Scienze Fisiche e Matematiche di Napoli, 2, 106, 104 pp.

Charollais, J., \& Badoux, H. (1990). Guide géologique régional. Suisse lémanique, Pays de Genève et Chablais (p. 224). Paris: Masson.

Charollais, J., Busnardo, R., Clavel, B., Decrouez, D., Delamette, M., Gorin, G., et al. (1988). Notice explicative de la feuille AnnecyBonneville au 1/50000 (p. 139). Orléans: B.R.G.M.

Charollais, J., Hochuli, H.A., Oertli, H.J., Perch-Nielsen, K., Toumarkine, M., Rögl, F., Pairis, J.-L. (1980). Les Marnes à Foraminifères et les Schistes à Meletta des chaînes subalpines septentrionales (Haute-Savoie, France). Eclogae Geologicae Helvetiae, 73, 9-69.

Charollais, J., \& Wellhäuser, F. (1963). Contribution à l'étude des Marnes à Foraminifères des chaînes subalpines (Haute-Savoie, France). Bulletin der Vereinigung Schweizerischer PetroleumGeologen und Ingenieuren, 29, 21-38.

Constantin, P. (1999). Oligocene-Lowermost Miocene fossil fishfauna (Teleostei) from Romanian Eastern Carpathians. Geo -eco -marina, 4, 119-134.

Danil'chenko, P. G. (1960). Bony fishes of the Maikop deposits of the Caucasus. Izdatel'stvo Akademii nauk SSSR Moskva, 78, 3-207. [in Russian, translated in English by the Israel Program for Scientific Translation 1967].

Danil'chenko, P. G. (1962). Fishes from the Dabakahn series of Georgia. Paleontologicheskii Zhurnal, 1, 111-126.

Fröhlicher, H., \& Weiler, W. (1952). Die Fischfauna der unterstampischen Molasse des Entlebuchs, Kt Luzern, und ihre paläogeographische Bedeutung. Eclogae Geologicae Helvetiae, 45, 1-35.

Gago, F. J. (1998). Osteology and phylogeny of the cutlassfishes (Scombroidei: trichiuridae). Natural History Museum of Los Angeles County, contribution in Science, 476, 1-79.

Gaudant, J., Mondain, P.-H., \& Decrouez, D. (1994). Découverte d'un Palaeorhynchus dans les «Schistes à Meletta » du synclinal de Champlaitier (Massif des Bornes, Haute-Savoie, France). Eclogae Geologicae Helvetiae, 87, 995-1005. 
Gorin, G., Gülacar, F., \& Cornioley, Y. (1989). Organic geochemistry, maturity and palaeoenvironment of Upper Kimmeridgian and Lower Tertiary organic-rich samples in the southern Jura (Ain, France) and subalpine massifs (Haute-Savoie, France). Eclogae Geologicae Helvetiae, 82, 491-515.

Gregorová, R. (2010). Osteological and morphological analysis of the scabbardfish Anenchelum glarisianum Blainville, 1818 (Trichiuridae) from the Menilitic Formation of the Moravian part of West Carpathians (Oligocene, Rupelian). Acta Musei Moraviae, Scientiae geologicae, 95, 141-149.

Gregorová, R. (2011). Fossil fish fauna (Teleostei, Selachii) from the Dynów marlstone (Rupelian, NP 23) of the Menilitic Formation at the locality of Litenčice (Czech Republic). Acta Musei Moraviae, Scientiae geologicae, 96, 3-33.

Gregory, W.K. (1933). Fish skulls-a study of the evolution of natural mechanisms. (pp. 481). Malabar, Florida: The American Philosophical Society.

Heckel, J. J. (1850). Beiträge zur Kenntniss der fossilen Fische Oesterreichs. Denkschriften der kaiserlichen Akademie der Wissenschaften, Mathematisch-Naturwissenschaftliche Classe, 1, 201-242.

Horbatsch [Gorbach], L.P. (1956). Ikhtiofauna i usloviya obrazovaniya otlozheniy menilitovoy serii karpat (Fish fauna and conditions of formation of the deposits of the Menilite series of the Carpathians). Avtoreferat dissertacii na souskanie ychenoy stepeni kandidata geologo-mineralogicheskih nauk, geologicheskii fakultet, Lvovskii gosydarstvennyi universitet im. iv. Franko. 1-12.

Jerzmanska, A. (1968). Ichtyofaune des couches à Ménilite (Flysch des Karpathes). Acta Palaeontologica Polonica, 13, 379-488.

Jonet, S. (1958). Contributions à l'étude des schistes disodyliques oligocènes de Roumanie. La faune ichtyologique de Homoraciu District de Prahova (112 pp.). Lisboa.

Kotlarczyk, J., Jerzmanska, A., Swidnicka, E., \& Wiszniowska, T. (2006). A framework of ichthyofaunal ecostratigraphy of the Oligocene-early Miocene strata of the Polish Outer Carpathian Basin. Annales Societatis Geologorum Poloniae, 76, 1-111.

Kramberger, D. (1879). Beitrage zur Kenntnis der fossilen Fische der Karpathen. Palaeontographica, Cassel, 26, 53-68.

Leriche, M. (1910). Les poissons Oligocènes de la Belgique. Mémoires du Musée Royal d'Histoire Naturelle de Belgique, 5, 363.

Martini, J. (1968). Note sur la migration du géosynclinal subalpin savoyard à la fin de l'Eocène et au début de l'Oligocène. Compte Rendu des Séances de la Société de Physique et d'Histoire Naturelle de Genève, 3, 79-89.

Meulenkamp, J. E., \& Sissingh, W. (2003). Tertiary palaeogeography and tectonostratigraphic evolution of the Northern and Southern
Peri-Tethys platforms and the intermediate domains of the African-Eurasian convergent plate boundary zone. Palaeogeography, Palaeoclimatology, Palaeoecology, 196, 209-228.

Paucã, M. (1930). Revision der fossilen Anenchelum-und CaprosArten. Bulletin de la section scientifique de l'Académie roumaine, 13, 177-183.

Paucã, M. (1934). Die fossile Fauna und Flora aus dem Oligozän von Suslăneşti-Muscel in Rumänien. Eine systematische und palaobiologische Studie. Anuarul Institutului Geologic al Romàniei, Bucuresti, 16, 575-668.

Pharisat, A. (1991). La paléoichthyofaune du Rupélien de Froidefontaine (Térritoire de Belfort). Annales Scientifiques de l'Université de Besançon, $3^{\text {ème }}$ série, Géologie 4, 13-97.

Pharisat, A., \& Micklich, N. (1998). Oligocene fishes in the western Paratethys of the Rhine Valley Rift System. Italian Journal of Zoology, 65(S1), 163-168.

Rath, G. (1859). Beitrag zur Kenntnis der fossilen Fische des Plattenberges im Canton Glarus. Zeitschrift der Deutschen Geologischen Gesellschaft, 11, 108-132.

Schegg, R. (1993). Thermal maturity and history of sediments in the North Alpine Foreland Basin (Switzerland, France) (194 pp.). Publications du Département de Géologie et Paléontologie, Université de Genève, Suisse, 15.

Simionescu, I. (1905). Sur quelques Poissons fossiles du Tertiaire roumain. Annales Scientifiques de l'Université de Jassy, 5, 1-17.

Starks, E. C. (1902). The shoulder girdle and characteristic osteology of the hemibranchiate fishes. Proceedings U.S. National Museum, 25, 619-634.

Starnes, W. C. (1988). Revision, phylogeny and biogeographic comments on the circumtropical marine percoid fisch family priacanthidae. Bulletin of Marine Science, 43, 117-203.

Taverne, L., \& Nolf, D. (2010). Les Priacanthidae (Teleostei, Perciformes) des Sables de Lede (Éocène moyen, Belgique): ostéologie et otolithes. Bulletin de l'Institut Royal des Sciences Naturelles de Belgique. Sciences de la Terre, 80, 187-243.

Weiler, W. (1928). Beitrage zur Kenntnis der tertiären Fische des Mainzer Beckens II. 3. Teil. Die Fische des Septarientones. Abhandlungen der Hessischen Geologischen Landesanstalt zu Darmstadt, 8, 1-63.

Weiler, W. (1932). Die Fischfauna der unteren und oberen Meeresmolasse Ober-bayerns. Neues Jahrbuch für Mineralogie, Geologie und Paläontologie, 68, 305-352.

Weiler, W. (1955). Untersuchungen an Fischen aus dem Alttertiär der Umgebung von Basel. II. Palaeontologischer Teil. Eclogae Geologicae Helvetiae, 48, 430-447.

Wettstein, A. (1886). Über die Fischfauna des tertiären Glarnerschiefers. Mémoires de la Société Paléontologique Suisse, Bâle, 13, $5-103$. 